\title{
Methods of physiotherapeutic management used in the treatment of secondary lymphoedema in the Holycross Cancer Centre in Kielce
}

\section{Metody postępowania fizjoterapeutycznego stosowane w leczeniu wtórnych obrzęków limfatycznych w Świętokrzyskim Centrum Onkologii w Kielcach}

\author{
Anna Opuchlik ${ }^{1,2}$, Małgorzata Biskup², Anna Włoch², Magdalena Lipińska-Stańczak³, Anna Lipińska 2,4 \\ ${ }^{1}$ Institute of Physiotherapy, Faculty of Physical Education and Tourism, Holy Cross University, Kielce, Poland \\ Head of Institute: Prof. Janusz Zdebski MD, PhD \\ ${ }^{2}$ Holycross Cancer Center, Kielce, Poland \\ Head of Centre: Stanisław Góźdź MD, PhD \\ 3Department of Pathology, Institute of Nursing and Midwifery, Faculty of Health Sciences, Jan Kochanowski University, Kielce, Poland \\ Head of Department: Prof. Anna Nasierowska-Guttmejer MD, PhD \\ ${ }^{4}$ Rehabilitation of Hearing and Balance Organs, Institute of Physiotherapy, Faculty of Health Sciences, Jan Kochanowski University, \\ Kielce, Poland \\ Head of Institute: Prof. Stanisław Bień MD, PhD
}

Studia Medyczne 2014; 30 (2): 123-130

Key words: post lymphadenectomy complication, mastectomy, complex physiotherapeutic management.

Słowa kluczowe: powikłania po limfadenektomii, mastektomia, kompleksowe postępowanie fizjoterapeutyczne.

\begin{abstract}
Lymphoedema is a serious problem in patients treated for malignant neoplasm. The removal of regional lymph nodes lymphadenectomy - is an inherent consequence of the surgical treatment of malignant neoplasm of breasts, genitals, prostate, skin cancer, salivary glands cancer and many others. The basic methods of conservative treatment of this chronic disease include complex methods of physiotherapy. The aim of this study is to present the rules of rehabilitation of patients treated for lymphoedema, which have been adopted by the team of the Department of Rehabilitation in the Holycross Cancer Centre in Kielce. This paper presents complex methods of physiotherapeutic management and discusses their availability and practical application in Polish health care institutions.
\end{abstract}

\section{Streszczenie}

Obrzęk limfatyczny stanowi poważny problem wśród pacjentów leczonych z powodu nowotworów złośliwych. Usunięcie regionalnych węzłów chłonnych - limfadenektomia, jest nieodłącznym skutkiem operacyjnego leczenia m.in. nowotworów złośliwych gruczołu piersiowego, narządów płciowych, prostaty, skóry, ślinianek. Do podstawowych sposobów leczenia zachowawczego tej przewlekłej choroby należą kompleksowe metody fizjoterapeutyczne. Celem pracy jest przedstawienie zasad usprawniania chorych leczonych z powodu obrzęków limfatycznych, jakie zostały przyjęte przez zespół Zakładu Rehabilitacji w Świętokrzyskim Centrum Onkologii w Kielcach. W pracy zaprezentowano kompleksowe metody postępowania fizjoterapeutycznego oraz omówiono ich dostępność i praktyczne zastosowanie w polskich placówkach służby zdrowia.

\section{Introduction}

Lymphoedema is a serious health, psychosocial and economic problem among patients treated for malignant tumours. The removal of regional lymph nodes - lymphadenectomy - is an integral part of the surgical treatment of malignant tumours of breasts, genitals, prostate, skin cancer, salivary glands cancer and many others. Their absence causes failure of the lymphatic system, which is characterised by difficult flow of lymph with its simultaneous accumulation in the subcutaneous tissue, the image of which is secondary lymphoedema [1]. The causes of this complication also include the used complementary therapy (radiotherapy), injuries and overload of limbs, previous inflammation and obesity [2, 3]. Untreated lymphoedema leads to intensification of its symptoms: an increase in limb volume, restrictions on the range of joint mobility, occurrence of their deformation and frequent inflammation, which results in deterioration of the functional status of patients. Because the disease is of a chronic nature, a non-invasive therapy system has been developed, which has a calming effect on its symptoms, but it requires good cooperation between the physiotherapist and the pa- 


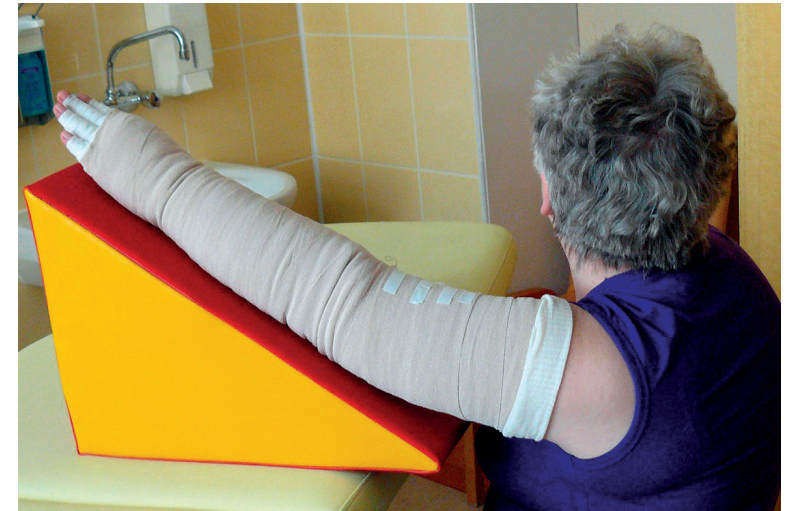

Figure 1. The use of compression therapy of the upper left limb during phase I of the treatment with the CDT method

tient, as well as the use of financial resources. It is noted that it is possible to maintain long-term effects of the treatment only in the group of patients following the methodological assumptions of the physiotherapeutic complex management $[4,5]$.

\section{Methods of physiotherapeutic management}

The largest group of patients with lymphoedema undergoing physiotherapy procedures in the Department of Rehabilitation in the Hollycross Cancer Centre (HCC) are patients after radical treatment of breast cancer. The patients undergo the Complex Decongestive Therapy (CDT) (German: Komplexe Pysikalische Entstauungstherapie (KPE), also called in English: Decongestive Lymphatic Therapy (DLT)), which includes: manual lymphatic drainage (MLD), multi-layer bandaging (compression therapy) (Figure 1), decongestive gymnastics and skin care [6, 7].

In phase I of the treatment (decongestive) the mentioned techniques are used daily for a period of time

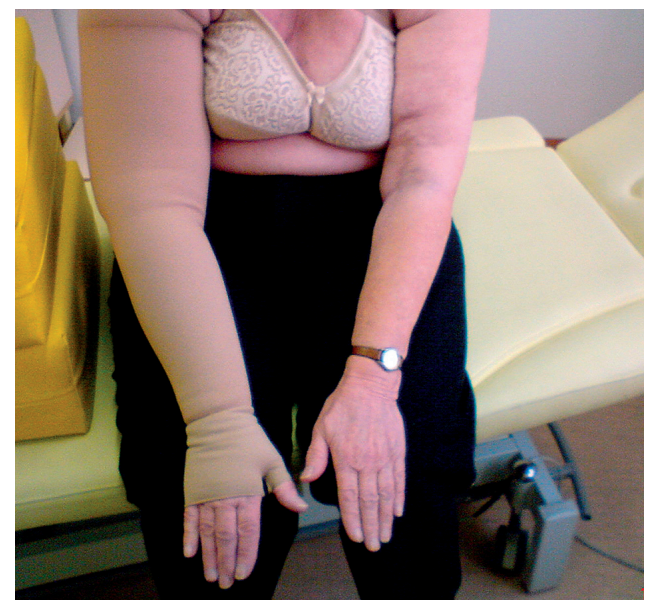

Figure 2. A patient in the course of phase II of the CDT method with a compression sleeve on her upper right limb dependent on the degree of swelling advancement in order to cause a reduction of fluid and proteins in the intratissue space, which causes a significant reduction in the size of the swollen limb. In phase II (fixing-optimizing) the effect obtained earlier is sustained through the use of self-massage, decongestive gymnastics and compression therapy (Figure 2) in the form of elastic compression materials worn by the patient [6].

Manual lymphatic drainage has a significant impact on the production of lymph, but it also increases lymphangio motor activity. This technique is based on Vodder's grips: constant circular, rotating, pumping and drawing motions performed in 1-second rhythms with 5-7 repetitions in a given area. The MLD should start with preparatory steps, involving preparation of the areas lying closer to the oedema fluid located in a distal segment (area of neck and trunk). Only after such preparation can performance of the techniques in the region of the limb take place - in the direction from the proximal to the distal part. The character of the grips cannot be based on strong stimuli because it causes contraction of the muscular layer on the lymphatic vessel wall. The MLD does not require lubricants, as they prevent formation of stretching stimuli and the phase of alternating, harmonious shift and relaxation [8].

In compression therapy in phase I of CDT lowstretch bandages are used, which maintain the effects of the performed MLD, increase the efficiency of the muscular-articular pump, facilitate penetration of the tissue fluid to the initial lymph vessels, reduce the volume of the swollen limb, facilitate regeneration of fibrosis (application of agents with polyurethane foam, e.g. Mobiderm ${ }^{\circledR}$ ) and reduce the risk of inflammation [9-11]. The patient, after application of multi-layered bandages, keeps them on them for $24 \mathrm{~h}$ and removes them before manual lymphatic drainage. In phase II of CDT, the selection of compression products is dependent on the severity of the oedema, the patient's tolerance or their lifestyle. During the application of compression in both the decongestive phase and the fixing-optimizing phase, the patient should perform movement exercises; the aim is to increase the effect of the compression therapy by reducing the volume of retained interstitial fluid, to increase the venous blood return and to improve the functioning of the lymphatic vessels $[9,10]$. Properly selected sequences of contraction and relaxation of particular muscles also prevent the formation of muscular-articular contractures and delay the development of soft tissue fibrosis [9]. Decongestive exercises are performed in the drainage positions with the use of gravity. Strenuous and rapid movements and long-term isometric tension should not be used $[10,12]$. The introduction of breathing exercises is beneficial because it causes an increase in fluctuations of negative pressure in the chest, which favours the return of venous blood to the heart and suction of lymph into the venous system 


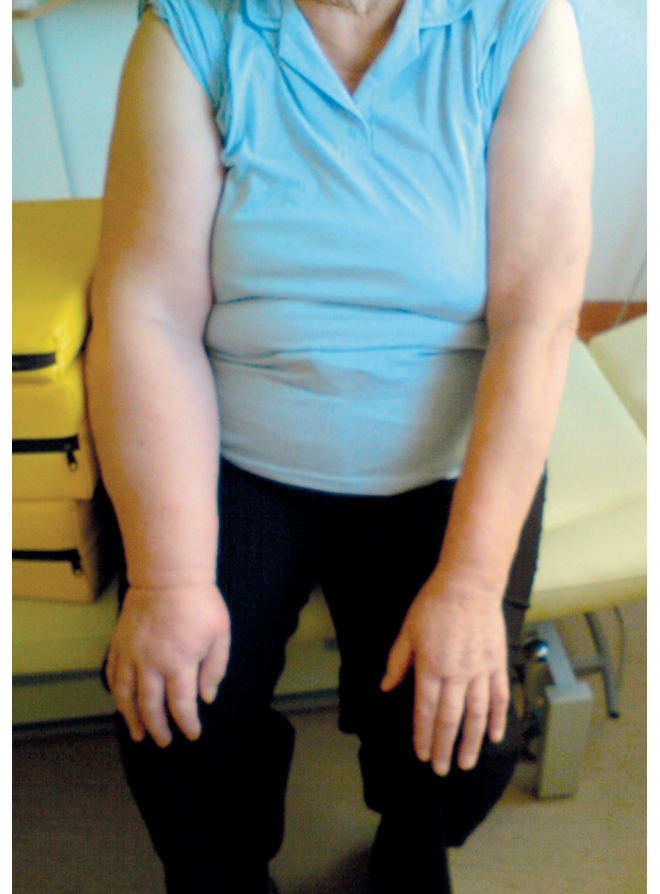

Figure 3. Upper right limb before applying CDT

$[11,12]$. Nursing consists of putting care cream or lotion at $\mathrm{pH} 5.5$ on the pre-washed and dried skin. Such a simple treatment protects the skin from excessive drying during compression therapy. This element of therapy cannot be omitted, especially in patients with high severity of oedema. Negligence of hygiene can lead to abrasions, ulcers and inflammation [9].

The CDT method is considered to be the most effective conservative method of lymphoedema treatment [5, 13-15] (Figures 3, 4).

In patients with greater progression of oedema in phase I of the CDT treatment, the following are additionally introduced before applying the bandages: a pneumatic massage, a whirlpool massage and a mechanical massage (vibratory) - a deep oscillation with the use of a Hivamat ${ }^{\circledR}$ device and/or electrical stimulation of smooth muscles of the lymphatic system with a Limpha-Vision ${ }^{\circledR}$ device [16-18].

A pneumatic massage, also called a broken pneumatic compression, is performed with the use of various devices equipped with multi-chamber sleeves and legs. The treatment consists of cyclical filling and emptying of chambers with air using a pump. When under pressure, the reduced hydrostatic pressure in the tissue is increased and the 'muscle pump' facilitating the outflow of excess liquid from the limb is supported. During the compression the reserve in the intercellular spaces for the outflowing fluid is initiated, allowing penetration of the lymph to collecting vessels. However, in the phase of decompression the vessels are filled, which contributes to better lymph transport.

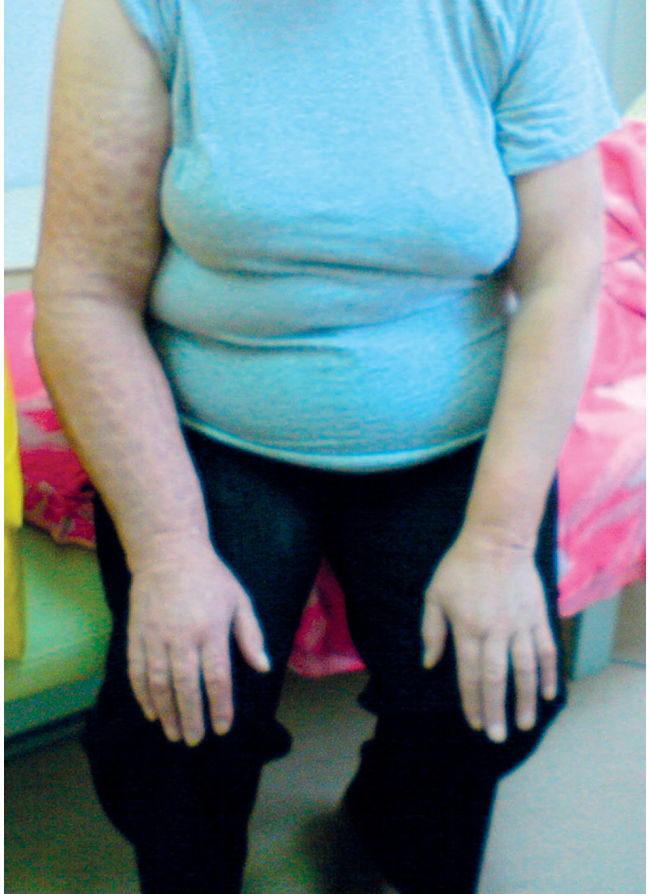

Figure 4. Upper right limb after 2-week treatment with the CDT method

Rhythmic compression changes support the outflow of venous blood without interfering with the inflow of arterial blood, on condition that the pressure in the sleeve or leg is maintained so that it does not exceed the diastolic blood pressure. Possible pressure amplitudes in each chamber are $20-140 \mathrm{~mm} \mathrm{Hg}$. These parameters are determined by the physiotherapist, depending on the degree of oedema. Oedema of a soft nature requires determination of the compression time three-times longer than the time of the break, i.e. $3: 1$ (45: 15 s). However, in irreversible oedema the time is shorter, i.e. $1: 1(30: 30 \mathrm{~s})$. The time of all the sequences is $40-60 \mathrm{~min}$. Settled and more progressed oedemas undergo treatment with a shorter time of compression and lower pressures in the chambers [10, 19]. In this group of patients, it is also recommended to use a pneumatic compression at home, which is connected with the purchase of a suitable device [20].

The vibration generated by using a Hivamat ${ }^{\circledR}$ is based on an intermittent electrostatic field. Movements of the therapist's hands or the device cause a pumping and vibrating action in the selected frequency range $(5-200 \mathrm{~Hz})$. This leads to stimulation of the natural peristalsis of the lymphatic system. A deep oscillation also causes a reduction in pain and tissue tension, thereby contributing to its relaxation.

In patients with secondary lymphatic oedema, a deep oscillation should always be performed in accordance with the methodical assumptions of manual lymphatic drainage. In the case of oedema with soft consistency, it is recommended to use doses of medi- 
Table 1. Standards of physiotherapeutic management in the Holycross Cancer Centre in patients with limb lymphoedema

\begin{tabular}{|c|c|c|}
\hline Degree & Symptoms & Treatment \\
\hline $0^{\circ}$ & Absence of clinical symptoms & Prevention \\
\hline $1^{\circ}$ & $\begin{array}{l}\text { Reversible oedema, soft or plastic } \\
\text { disappears after limb elevation, after } \\
\text { compression with a thumb, the hollow } \\
\text { quickly disappears, differences in } \\
\text { metric measurements in at least two } \\
\text { circumferences: } 1.5-2 \mathrm{~cm}\end{array}$ & $\begin{array}{l}\text { MLD - Manual lymphatic drainage } \\
\text { Pneumatic m.: } 50 \mathrm{~mm} \mathrm{Hg} \\
\text { Team or individual exercise } \\
\text { Education - self-massage and instruction on antioedema } \\
\text { prevention } \\
\text { Deep oscillation - Hivamat } 25-80 \mathrm{~Hz} \text { or Limpha-Vision } \\
\text { After the ending of the first treatment phase: kinesio taping }\end{array}$ \\
\hline$\|^{\circ}$ & $\begin{array}{l}\text { Spontaneous-irreversible oedema, hard } \\
\text { does not disappear after elevation } \\
\text { of the limb, progressive hardening: } \\
\text { after compression with a thumb, } \\
\text { the hollow remains for a long time - } \\
\text { fibrosis (fibrosclerosis) differences in } \\
\text { metric measurements in at least two } \\
\text { circumferences: } 2.5-5 \mathrm{~cm}\end{array}$ & $\begin{array}{l}\text { Whirlpool massage (warm temperature) or vibrating } \\
\text { before CDT } \\
\text { CDT: manual lymphatic drainage, compression therapy } \\
\text { (bandaging), decongestive exercise, skin care } \\
\text { Team exercise (in bandages) or in decompression } \\
\text { and self-supported pneumatic massage: } 60-90 \mathrm{~mm} \mathrm{Hg} \\
\text { and deep oscillation - Hivamat } 25-50 \mathrm{H}-\text { In the case } \\
\text { of contraindications of bandaging } \\
\text { After completion of phase I of the treatment: wearing } \\
\text { compression products, in the case of contraindications: } \\
\text { kinesio taping }\end{array}$ \\
\hline$\| I^{\circ}$ & $\begin{array}{l}\text { Lymphatic elephantiasis } \\
\text { Hard and irreversible oedema } \\
\text { progressive limb deformity, present } \\
\text { sclerosis of the skin (condylomata and } \\
\text { warts) and a change in colour (bluish- } \\
\text { brown), excessive lymph, limited } \\
\text { movement in the joints, local immunity } \\
\text { reduction - susceptibility to infection } \\
\text { (rose) after compression with a thumb } \\
\text { no trace of the hollow, differences in } \\
\text { metric measurements in at least two } \\
\text { circumferences: above } 5.5 \mathrm{~cm}\end{array}$ & $\begin{array}{l}\text { Whirlpool massage (warm temperature) or vibrating } \\
\text { before CDT } \\
\text { CDT: manual lymphatic drainage, compression therapy } \\
\text { (bandaging), decongestive exercise, skin care } \\
\text { Team exercise (in bandages) or in decompression } \\
\text { and self-supported Pneumatic massage: } 80-90 \mathrm{~mm} \mathrm{Hg} \\
\text { and Deep oscillation - Hivamat } 105-50 \mathrm{H}-\text { in the case } \\
\text { of contraindications of bandaging } \\
\text { After completion of phase I of the treatment: wearing } \\
\text { compression products, in the case of contraindications: } \\
\text { kinesio taping }\end{array}$ \\
\hline
\end{tabular}

um frequency, and in more progressed - irreversible and hard - low frequency [21, 22].

An electrostimulation treatment using low-frequency currents, produced by a Lympha-Vision ${ }^{\circledast}$ device is a method of stimulating and regulating the lymphatic system. Stimulation of the autonomic nervous system leads to activation of lymphatic vessels, normalising the cyclical contractile and decontractile effects. Higher doses of the current stimulate skeletal muscles, so called 'muscle pump', which has an indirect impact on the growth of lymph and venous blood transport in the area of the swollen limbs and trunk [18].

Before starting phase II of the treatment, patients are educated in the scope of prevention and self-therapy actions - self-massage, decongestive exercise, and the rules of wearing compression products. In our centre the antiedematous prophylaxis is already introduced in the early period of hospital treatment in patients of oncological and gynaecological surgery wards -1 day after lymphadenectomy surgery. For this purpose, instructions on conduct in different situations of life are provided. Special booklets helping patients with self-therapy and reminding them the principles of lymphoedema prevention have been developed [23]. In order to facilitate the classification of this complication and to assist in the proper selection of physiotherapy methods, standards of procedure for lymphatic oedema of the limbs have been developed (Table 1). It is necessary to note that, prior to the introduction of the treatment, each patient's condition is assessed individually so that the therapy can give the most effective results.

The CDT is also used in another, less numerous group of patients with secondary lymphoedema of the lower limbs, treated due to complications after surgical and complementary procedures in the area of the pelvis - inguinal lymphadenectomy (Figures 5, 6).

A new method used in physiotherapy of oedema is kinesiology taping (KT), the aim of which is to extend the effects of the therapy after its completion. In the concept, a kind of tape with properties similar to the parameters of the human skin is used [15].

The KT philosophy is based on allowing free movement through restoration of normal fluid perfusion, lymph flow activation, activation of the analgesic system and regulation of muscle tone, and correction of abnormal positions of joint structures. The mecha- 


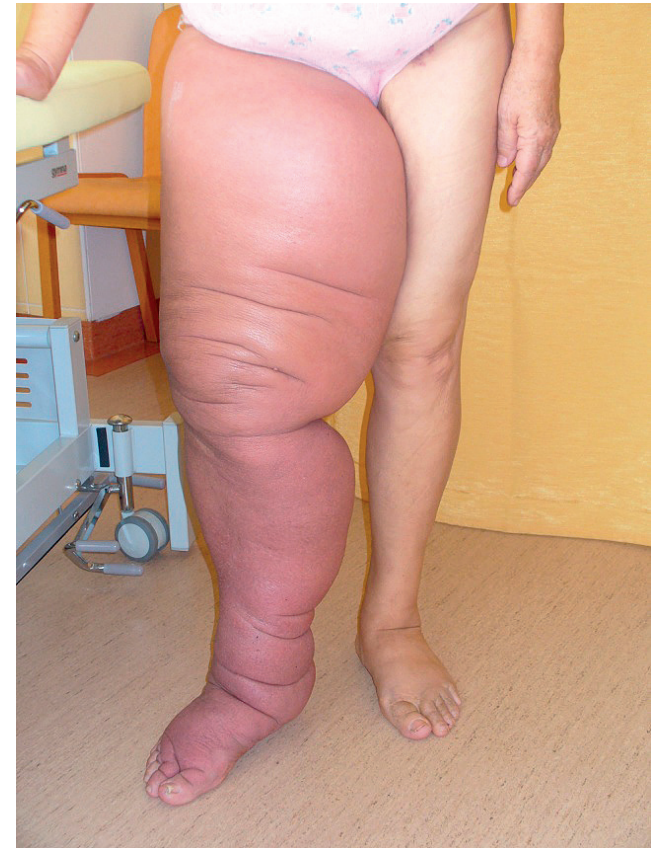

Figure 5. Lower right limb before starting treatment of phase I of CDT

nism of the tape action relies on gentle stimulation of the epidermis layers, which affects the occurrence of changes in the fascia area [24].

Lymphatic applications cause gentle pulling of the skin, increasing the space between the dermis and fascia. This technique causes reduction in stasis and lymphoedema, and thus improves the microcirculation of lymph [25, 26].

Applications should be used on dry, degreased skin, free of excessive hair growth, with activation of glue by vigorous rubbing.

The essence of lymphatic applications is the connection of a lymphatic oedema area with the nearest, functioning lymph nodes - from the proximal to the distal parts. It should be adhered to stretched skin, without stretching the plaster, so as to obtain some free space under it. The best form of KT in lymphoedema is the "Fork" technique, in which a tape $5 \mathrm{~cm}$ wide is divided into four equal strips. At the length of $5 \mathrm{~cm}$, the uncut part is the base, which is also the beginning of the application. The base is attached in the location of the regional lymph nodes or along lymphatic vessels in the direction compatible with the flow of lymph [27-29]. In the absence of the possibility to stretch the skin, application of separate strips stuck with slight (15-25\%) stretch can be used [30]. The use of kinesio taping for lymphoedema physiotherapy (Figure 7) efficiently supports healing processes and contributes to the improvement in the patient's condition, being a perfect complement to the complex antioedema treatment [26].

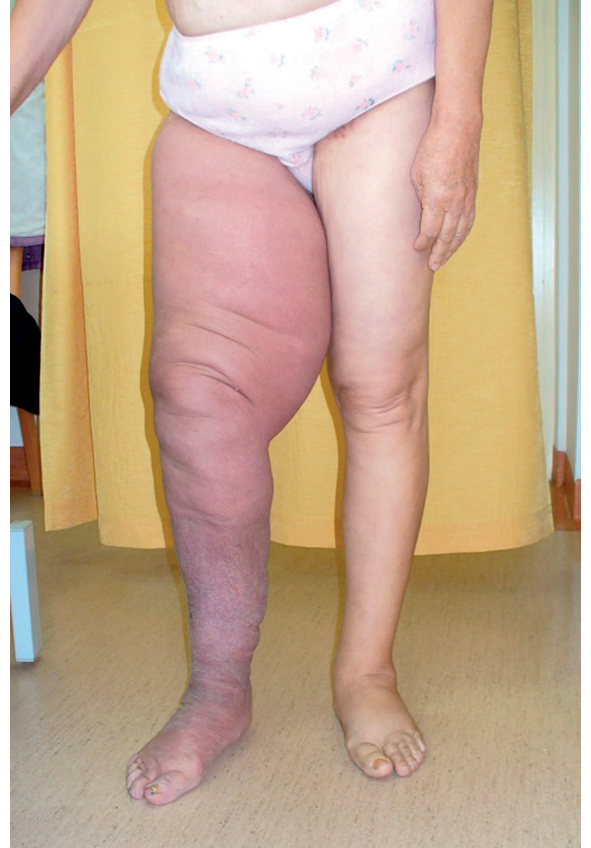

Figure 6. View of the lower limb after 3 months of CDT treatment

\section{Discussion}

In the available literature, the greatest controversy is associated with the use of manual lymphatic drainage. Földi believes that the discussion on the problem of the damaging impact of the massage on lymphatic vessels has existed for more than 60 years and is still not fully resolved. According to the author, in the majority of patients lymphatic massages bring minimal improvement, but they do not cause worsening of the patients' clinical status [31].

On the other hand, the suspicion that MLD can facilitate the spread of cancer cells has not been con-

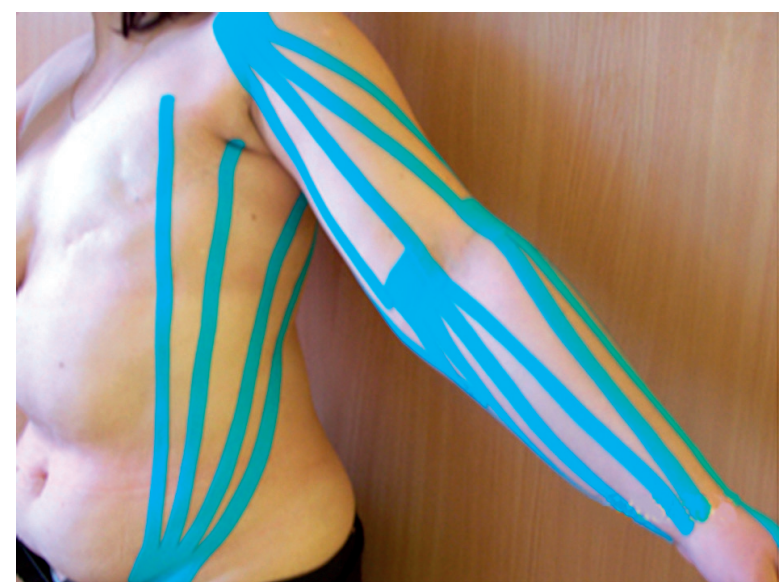

Figure 7. Kinesiology Taping - lymphatic applications 'fork' in the area of the trunk and upper limb in a patient after left-hand mastectomy 
firmed in practice. Studies suggest a beneficial effect of manual lymphatic drainage on the possibility of presenting the tumour cells to natural immune cells present in the lymph. This creates conditions for destruction of potentially existing metastatic focuses $[13,32]$.

Our team conducted research evaluating the effectiveness of this method [5, 33]. In the study carried out in the years 1998-2005, 50 (100\%) women after mastectomy with lymphoedema of the upper limb, subjected to the CDT method, were assessed in two phases of treatment: I - after 2-4 weeks and II - after 4-6 months. Application of CDT caused a reduction in progression of lymphoedema both after 2-4 weeks of the physiotherapeutic procedure and in the later study, a statistically significant and stable reduction of oedema was found in all the measurement points on the limb. Thus, the impact of the CDT method resulted in a reduction of disparities between the upper limb on the operated side of the breast, and the opposite limb. It has been proven that it brings a permanent reduction in the size of oedema. Obtaining beneficial effects allowed the patients to achieve better performance of the upper limb. A statistical analysis of the results identified a significant difference between the measurements carried out before and after the treatment [5].

Grądalski [34] suggested disseminating in Poland a method of complex physiotherapy - CDT involving the application of a manual lymphatic massage, a pneumatic massage, bandaging limbs, physical exercise, skin care and elevation of the limb. He performed lymphoedema treatment in 23 women after mastectomy, in two stages. The first, a 2-week stage, was associated with educating patients and their families, and implementing a complex physiotherapy. In this stage, apart from four elements obligatory in CDT, the author additionally introduced a pneumatic massage. The second stage was carried out at home and it involved systematic performance of nursing recommendations, wearing an elastic sleeve and doing previously learnt exercises [34].

Despite the patients' access to professional information on prevention of lymphoedema, which is usually provided by physiotherapists, not all the patients apply these recommendations. Dziura and Grądalski [35] conducted research to determine the degree of knowledge of oedema prevention principles and the frequency of following the recommendations received by patients after mastectomy. The authors found that patients, despite their awareness of the risks and factors triggering lymphoedema, did not apply the principles of anti-oedematous conduct [35].

On the basis of long-standing observation of patients behaviour in the Holycross Cancer Centre, treated for lymphatic oedema, it can be stated that their reactions to the suggested method of therapy do not always comply with its assumptions. The proof of this thesis are the patients who are reluctant to comply with the recommendations obligatory in phase II of the CDT method - wearing compression products. Patients often do not accept the suggestions that they should purchase, non-reimbursed by the National Health Fund, sleeves or compression stockings, despite the awareness of their therapeutic significance. Compression products after about 6 months of systematic use are destroyed and need to be replaced with new ones. Thanks to these products the state of the oedema undergoes further stabilisation [33, 36]. Frequently, patients resign from purchasing such items because of their lack of financial means. The physiotherapeutic team's motivation is certainly an important factor in achieving satisfactory treatment effects later - after the completion of the phase I of CDT. Another opinion is presented by the patients who are embarrassed to wear elastic sleeves, or think that they do not allow them adequate comfort in everyday activities (Activities of Daily Living - ADL). For this group of patients an effective way to sustain the effects of the therapy is the use of kinesiology taping and repetition of phase I of the CDT during the period of oedema worsening $[2,6,13]$.

The Department of Rehabilitation conducted the assessment of the impact of kinesio taping application on lymphoedema of the upper limb in women after mastectomy. The study confirmed a beneficial effect of KT on the condition of lymphoedema [26].

Tsai et al. [37] confirmed the lack of statistically significant differences in the effectiveness of reducing oedema in the first group with the use of the CDT method and in the group using CDT plus the replacement of bandages with kinesio taping. They concluded that the KT tape can replace compression therapy with the use of multilayer bandages, and both methods are effective in lymphoedema treatment.

Schwenzer and Kumbrink from the Clinic in Dortmund were inspired to perform $\mathrm{KT}$ techniques after manual lymphatic drainage, because they believe that the use of lymphatic application has (quote): '...a positive effect on the lymphatic system'. Moreover, in the opinion of the patients of Dortmund Clinical Hospital, 'elastic tapes' are a pleasant part of the therapy and are more comfortable to wear than compression sleeves [38]. A similar opinion is shared by patients treated in the HCC who do not accept wearing compression products and consider this method to be more comfortable.

In Poland, the list of medical services reimbursed by the National Health Fund (NHF) does not include the procedure known as 'Oedema treatment' [2]. Many centres do not perform these procedures under the contract with the NHF, and those who have decided to introduce them offer patients a limited scope of treatment or demand partial payment for the performed procedures (mostly the cost of buying a set of bandages). Physiotherapy procedures in ambulatory 
conditions that are refunded by the National Health Fund include only: lymphatic therapeutic massage, lymphatic mechanical therapeutic massage (pneumatic), kinesio therapy and mechanical massage (with instruments, e.g. vibratory). The methodology of CDT consists of four inseparable elements, and omitting one of them (compression therapy) will not provide good effects of treatment. In spite of these difficulties, the Holycross Cancer Centre introduced in 1998 the CDT method, providing a group of lymphoedema patients with care.

Currently, the treatment is carried out within the operation of the Department of Day Rehabilitation, as well as in an ambulatory setting.

Another centre implementing a complex program of physical therapy for this group of patients in sanatorium conditions is the Resort Enterprise 'Ustron' SA, where in 2011 the Ward of Lymphoedema Treatment was created [39]. Moreover, in some larger oncology centres such services are available to patients. However, smaller health care facilities lack any preservative treatment in this regard. Good documentation in numerous clinical research projects on the rules of reaction and the possibility of achieving results of CDT demonstrate the need for its common implementation in the health care system in Poland. Bodies financing and supervising the health care department should standardise the system of treating this chronic disease, prepare standards for prophylactic and therapeutic management, and specify the detailed rules for its financing. Development of such a program would facilitate physiotherapy specialists' work, and patients' access to free and effective treatment.

\section{Conclusions}

The advantage of complex physiotherapeutic management is the achievement of a satisfactory reduction in the size of lymphoedema. This process, however, requires great commitment from both physiotherapy specialists and patients. Continuation of the treatment by patients at home allows long-term results of the treatment to be maintained. Adoption of the standard programs of lymphoedema physiotherapeutic management reimbursed by the National Health Fund would contribute to their dissemination.

\section{References}

1. Tchórzewska H. Rehabilitacja w leczeniu raka piersi. In Rak piersi - nowe nadzieje i możliwości leczenia. Pawlicki M (ed.) $\alpha$-Medica Press, Bielsko-Biała 2002; 99-120.

2. Doś J, Gutowski P, Górska-Doś M. Występowanie oraz czynniki ryzyka obrzęku chłonnego u kobiet po operacji raka piersi. Yearbook of Pomorska Medical Academy in Szczecin 2009; 55: 30-4.

3. Petrek JA, Senie RT, Peters M, et al. Lymphedema in a cohort of brest carcinoma survivors 20 years after diagnosis. Cancer 2001; 92: 1368-77.
4. Williams AF, Vadgama A, Franks PJ, et al. A randomized controlled crossover study of manual lymphatic drainage therapy in women with breast cancer-related lymphoedema. Eur J Cancer Care 2002; 11: 254-61.

5. Opuchlik A, Lipińska A. Wyniki porównawcze metody kompleksowej fizycznej terapii udrażniającej z metodą manualnego drenażu limfatycznego i masażu pneumatycznego w leczeniu obrzęku limfatycznego kończyny górnej u kobiet po mastektomii. Orthop Quart 2010; 1: 95-112.

6. Földi M, Kubik S. Lehrbuch der Lymhologie fur Mediziner Und Physiotherapeute. Fischer Publisher, Stuttgart 1989.

7. Howell D. Complete decongestive therapy for lympedema following breast cancer treatment, The Cochrane Library 2008; 4: 1-5.

8. Földi M, Strößenreuther R. Podstawy manualnego drenażu limfatycznego. Urban \& Partner, Wrocław 2005; 469-72.

9. Chęciński P. Obrzęk chłonny. Termedia, Poznan 2010; 50-5.

10. Malicka I, Pawłowska K. Fizjoterapia chorych z obrzękami chłonnymi po leczeniu nowotworów złośliwych. In: Fizjoterapia $\mathrm{w}$ onkologii. Woźniewski M (ed.). PZWL, Warsaw 2012; 49-64.

11. Cavezzi A, Michelini S. Phlebolymphoedema from diagnosis to therapy. Edizioni PR, Bologna 1998; 119-25.

12. Hawro R, Bębenek M, Pudełko M. Wczesna pooperacyjna fizjoterapia po doszczętnym leczeniu raka gruczołu piersiowego. Physioterapy 1999; 7: 12-7.

13. Pyszora A. Kompleksowa fizjoterapia pacjentów z obrzękami limfatycznymi. Med Paliat Prakt 2010; 4: 23-9.

14. Doś J. Ocena skuteczności manualnego drenażu limfatycznego i terapii uciskowej w leczeniu obrzęku kończyny górnej u kobiet po operacji raka piersi. Praca doktorska. Pomorska Medical Academy, Szczecin 2008.

15. Bąk M. Fizjoterapia w przypadkach wtórnych obrzęków limfatycznych u kobiet po mastektomii. Biospołeczne skutki mastektomii. Materials of II Nat. Conf. AWF, Poznań 2001; 109-16.

16. Krukowska J, Terek M, Macek P, et al. Metody redukcji obrzęku limfatycznego u kobiet po mastektomii. Physioterapy 2010; 18: 3-10.

17. Woźniewski M. Znaczenie przerywanego masażu pneumatycznego w leczeniu wtórnego obrzęku chłonnego kończyny górnej. Polski Tyg Lek 1991; 30-31: 550-2.

18. Gieremek K, Rojczyk-Chmarek J, Śliwiński Z. Elektrostymulacja postępem $\mathrm{w}$ fizjoterapeutycznym leczeniu obrzęków chłonnych. Physioter Pol 2002; 2: 300-5.

19. Woźniewski M. Wczesne i odległe wyniki kompleksowego usprawniania chorych z wtórnym obrzękiem chłonnym kończyny górnej. Studia i Monografie. AWF, Wroclaw 1991; 24.

20. Gurda SO, Kostanoglu A, Cavdar I, et al. Comparison of compression with manual lymphatic drainage for treatment of breast cancer-related lympedema. Lymphat Res Biol 2012; 10: 129-35.

21. Trybulski R. Wykorzystanie systemu głębokiej oscylacji i elektrostymulacji limfangionu $\mathrm{w}$ procesie wspomagania leczenia ran i obrzęków. Limfologia w Praktyce 2012; 1: 33.

22. Jahr S, Schoppe B, Reisshauer A. Effect of treatment with low-intensity and extremely lowfrequency elect rostatic fields (deep oscillation ${ }^{\circledR}$ ) on breast tissue and pain in patients with secondary breast lymphoedema. J Rehabil Med 2008; 40: 645-50. 
23. Opuchlik A. Informator dla kobiet po amputacji piersi Holycross Cancer Center, Kielce 2005.

24. Kiebzak W, Kowalski IM, Pawłowski M, et al. Wykorzystanie metody Kinesiology Taping w praktyce fizjoterapeutycznej: literature review. Fizj Pol 2012; 12: 1-11.

25. Kase K. Clinical therapeutic applications of Kinesio Taping Method. Ikai Co. Ltd. Tokyo Japan 2003; 80-1.

26. Lipińska A, Śliwiński Z, Kiebzak W, et al. Wpływ aplikacji kinesiotapingu na obrzęk limfatyczny kończyny górnej u kobiet po mastektomii. Fizjoter Pol 2007; 7: 258-69.

27. Kinesio Taping Basic Course, Kinesio Taping Association, Training materials, Tokyo, Japan 2002

28. Kinesio Taping Upper Extermity, Kinesio Taping Association, Training materials, Tokyo, Japan 2003.

29. Śliwiński Z, Senderek T. Kinesiology taping. Part I and Part II. Training materials, Zgorzelec 2005.

30. Kase K, Wallis J, Kase T. Clinical therapeutic applications of Kinesio Taping method. Albuquerque, New Mexico 2003; 80-3.

31. Szostek M, Skórski M. Choroby naczyń chłonnych. Fundacja Polskiego Przeglądu Chirurgicznego, Warsaw 1996; 193-8.

32. Ochałek K, Grądalski T. Manual lymph drainage may not be a necessary component in lymphedema treatment. J Pain Symptom Manag 2010; 5: 1-2.

33. Opuchlik A, Migórska A, Dudkiewicz Z, et al. Przydatność metody kompleksowej fizycznej terapii udrażniającej w leczeniu obrzęku limfatycznego kończyny górnej u kobiet po mastektomii. Orthop Quart 2008; 4: 412-22.

34. Grądalski T. Kompleksowe leczenie zachowawcze w obrzęku limfatycznym po operacjach raka sutka. Postęp Rehabil 1997; 11: 59-67.

35. Dziura I, Grądalski T. Wiedza o czynnikach wyzwalających powstanie obrzęku chłonnego i stosowanie się do zaleceń profilaktycznych $\mathrm{u}$ chorych po mastektomii. Medical Rehabilitation 2008; 12: 14-8.

36. Doś J, Woźniewski M, Górska-Doś M. Podstawowe zasady kompleksowej fizycznej terapii udrażniającej w leczeniu obrzęków limfatycznych kończyn. Biospołeczne skutki mastektomii. AWF, Poznań 2001; 59-68.

37. Tsai HJ, Hung HC, Yang JL, et al. Could Kinesio Tape replace the bandage in decongestive lymphatic therapy for breast - cancer - related lymphodema? A pilot study. Support Care Cancer. Springer-Verlag 2009; 17: 1353-60.

38. Schwenzer C, Kumbrink B. Kinesio Taping und Lymphdrainage nach Brustkrebs-eine sinnvolle Kooperation zwischen Brust zentrum und Rehabilitationseinrichtung, http://www.kinesio taping.de/content_X/info/bericht01. php?PHPSESSID=a3823d67b5ff71e8b08a8ee623c4e73b. 15.11.2011.

39. Rybicka E, Marzec A, Doś J. Standardy leczenia chorych z obrzękiem limfatycznym w Ustrońskim Centrum Rehabilitacji Onkologicznej i Limfologii „Rosomak” w Przedsiębiorstwie Uzdrowiskowym „Ustron” SA. Limfologia w Praktyce 2012; 1: 37.

\section{Address for correspondence:}

Anna Opuchlik MD, PhD

Institute of Rehabilitation

Holycross Cancer Center

ul. Artwińskiego 3, 25-734 Kielce, Poland

Phone: +48413674171

E-mail: annaop@onkol.kielce.pl 